\title{
Клінічна ефективність у віддалений період відновлювального лікування хворих з ішемічною хворобою серця після хірургічної реваскуляризації хворих
}

\begin{abstract}
Мета роботи: вивчити клінічну ефективність у віддалений період санаторного етапу реабілітації хворих з IXC після XРM. Матеріали і методи. Обстежено 151 пацієнта з IXC після хірургічної реваскуляризації міокарда (XPM). 111 пацієнтів основної групи пройшли санаторне лікування. Курс лікування склав 21 день, після якого були надані рекомендації щодо модифікації способу життя. Пацієнти групи порівняння (40 осіб) не проходили санаторного лікування. Віддалені результати вивчали за даними амбулаторних карт пацієнтів (наявність інфаркту міокарда протягом 12 місяців після ХРМ, кількість госпіталізацій з приводу ускладнень IXC, кількість нападів стенокардії), всім пацієнтам проводили неінвазивні дослідження, які включали ЕКГ, ЕХоКС. 3 метою діагностики уражень коронарного русла пацієнтам із позитивною пробою на велоергометрі (ВЕМ) проводили коронарографію.

Результати досліджень та їх обговорення. За даними BEM, у 7,5 \% пацієнтів, які не проходили санаторний етап лікування, виявлено ознаки ішемії міокарда проти 1,5 \% пацієнтів в основній групі. Кількість нападів стенокардії, в результаті якої була проведена повторна процедура реваскуляризації (чрезшкірне коронарне втручання), в основній групі було виявлено у 3 (2,7\%) пацієнтів, тоді як у групі порівняння вірогідно більшим - у 5 (12,5 \%) пацієнтів (p<0,05).
\end{abstract}

Ключові слова: ішемічна хвороба серця; хірургічна реваскуляризація міокарда; віддаленні результати; санаторний етап.

Постановка проблеми і аналіз останніх досліджень та публікацій. На сьогодні хірургічні методи лікування ішемічної хвороби серця (IXC) вважають найефективнішими [6]. Саме тому ведення пацієнтів після операцій реваскуляризації міокарда актуальне у зв'язку із більш широким застосуванням сучасних інтервенційних технологій [4]. Хірургічна реваскуляризація міокарда (ХРМ) (стентування, аортокоронарне шунтування) істотно покращує якість життя пацієнтів з IXC, усуваючи або значно зменшуючи кількість ангінозних нападів, але вирішенню проблеми поліпшення коронарного кровотоку не завжди приділяється увага патогенетичним механізмам, що лежать в основі розвитку патології [9]. Прогноз пацієнта, який переніс ХРМ, здебільшого залежить не лише від успішного виконання втручання, а й від подальшої стратегії відновлювального лікування та медикаментозної терапії [5]. Як відомо, хворі після операції з реваскуляризації повинні пройти певні етапи лікування: ранній та пізній госпітальний етап і санаторний [7, 8]. Ефективність відновлювального лікування залежить значною мірою від повноцінності комплексів реабілітаційних заходів та дотримання строгої послідовності [1, 3].

Водночас аналіз даних літератури та наш власний досвід свідчить про те, що сьогодні мало уваги приділяється санаторному етапу, який є найбільш тривалим та дає змогу покращити віддалений прогноз і подовжити тривалість життя й поліпшити його якість.
Мета роботи: вивчити клінічну ефективність у віддалений період санаторного етапу реабілітації хворих із IXС після XРМ.

Матеріали і методи. Під нашим спостереженням був 151 пацієнт віком $(58,7 \pm 8,9)$ року після хірургічної реваскуляризації міокарда, які отримували стандартну медикаментозну терапію, а саме: нітрати, бета-блокатори, антагоністи кальцію, інгібітори АПФ ферменту, дезагреганти, діуретики, гіполіпідемічні препарати і комплекс санаторно-курортної реабілітації. Пацієнти основної групи (111 осіб) додатково проходили санаторно-курортне лікування в лікувально-оздоровчому комплексі “Біла акація” (м. Одеса). Протипоказанням для санаторно-курортного лікування були: часті та тривалі напади стенокардії напруги і спокою, нестабільна стенокардія; свіжий інфаркт міокарда; недостатність кровообігу IV ф. кл. NYHA; виражені порушення ритму; виражена артеріальна гіпертензія з ураженням внутрішніх органів, що погано піддається корекції; післяопераційні ускладнення; наявність супутніх захворювань, що супроводжуються лихоманкою; залишкові явища тромбоемболії в судини головного мозку. Курс лікування склав 21 день, після якого були надані рекомендації із модифікації способу життя. Пацієнти групи порівняння (40 осіб) не отримували комплексу санаторного лікування. Віддалені результати вивчали за даними амбулаторних карт 
пацієнтів (наявність інфаркту міокарда протягом 12 місяців після ХРМ, кількість госпіталізацій 3 приводу ускладнень IXC, кількість нападів стенокардії), всім пацієнтам проводили неінвазивні дослідження, які включали ЕКГ, ЕХоКС. 3 метою діагностики уражень коронарного русла пацієнтам із позитивною пробою на велоергометрі (BEM) проводили коронарографію.

ВЕМ проводили пацієнтам відповідно до стандартного протоколу [2]. При пробі з фізичним навантаженням найбільш інформативні для діагностики IXC на ЕКГ та діагностично значимі зміни сегмента ST ішемічного характеру. За суттєве приймається відстань дна сегмента на 1 мм та більше. Пробу вважали позитивною при зсуві сегмента ST вверх або вниз від ізоелектричної лінії на 1 мм та більше в точці, віддаленій від точки ј на 60 мс та /чи розвитку типового нападу стенокардії, негативною - при досягнені запланованої частоти серцевих скорочень (120 на 1 хв) при відсутності клінічних та електрокардіографічних критеріїв припинення проби.
Результати досліджень та їх обговорення. В обох групах у віддалений період летальних випадків не зафіксовано (табл. 1). В основній групі не було зафіксовано жодного інфаркту міокарда (IM), тоді як у групі порівняння - 1 (2,5 \%) пацієнт. Безпосередньою причиною IM був пізній тромбоз. Пацієнтам із рецидивом стенокардії проводили навантажувальний тест - ВЕМ, з метою визначення наявності ішемії міокарда. В основній групі пацієнтів у 2 (1,8 \%) пацієнтів було виявлено ішемію, яка клінічно ніяк не проявлялася. Цим пацієнтам було проведено коронарографію, в результаті якої значущих уражень не виявлено. В групі порівняння у 3 (7,5 \%) пацієнтів, за даними ВЕМ, виявлено ознаки ішемії міокарда. Цим пацієнтам було проведено коронарографію та виявлено рестенози. Кількість нападів стенокардії, в результаті якої проведено повторну процедуру реваскуляризації (черезшкірне коронарне втручання), в основній групі було виявлено у 3 (2,7 \%) пацієнтів, тоді як в групі порівняння вірогідно більшим - у 5 (12,5 \%) пацієнтів.

Таблиця 1. Віддалені результати хірургічної реваскуляризації міокарда хворих із ішемічною хворобою серця через 12 місяців після санаторного етапу реабілітації

\begin{tabular}{||l|c|c|c||}
\hline \multicolumn{1}{|c|}{$\begin{array}{c}\text { Показники } \\
\text { (кількість пацієнтів, \%) }\end{array}$} & $\begin{array}{c}\text { Група порівняння } \\
(\mathrm{n}=40)\end{array}$ & $\begin{array}{c}\text { Основна група } \\
(\mathrm{n}=111)\end{array}$ & $\mathrm{P}$ \\
\hline Летальність & $0(0)$ & $0(0)$ & $\mathrm{p}>0,05$ \\
\hline Інфаркт міокарда & $1(2,5)$ & $0(0)$ & $\mathrm{p}>0,05$ \\
\hline Наявність ішемії (ВЕМ)* & $3(7,5)$ & $1(1,5)$ & $\mathrm{p} \leq 0,01$ \\
\hline Кількість госпіталізацій* & $20(50,0)$ & $25(22,5)$ & $\mathrm{p} \leq 0,01$ \\
\hline Рецидив стенокардії (ЧКВ цільового ураження)* & $5(12,5)$ & $3(2,7)$ & $\mathrm{p} \leq 0,01$ \\
\hline $\begin{array}{l}\text { Загальна частота основних серцево-судинних } \\
\text { ускладнень }\end{array}$ & $8(20,0)$ & $14(12,6)$ & $\mathrm{p}>0,05$ \\
\hline \hline
\end{tabular}

Примітка. *Статистично вірогідна відмінність

Кількість госпіталізацій від загальних причин в основній групі склала 22,5 \%, що майже в 2 рази менше, ніж групі пацієнтів, які не проходили санаторно-курортне лікування. Аналогічну картину ми спостерігали і при вивчені кількості госпіталізацій з основних серцево-судинних ускладнень, так в основній групі цей показник був на 7,4 \% менше, ніж в групі порівняння.

\section{СПИСОК ЛІТЕРАТУРИ}

1. Аронов Д. М. Реабилитация больных ишемической болезнью сердца на диспансерно-поликлиническом этапе / Д. М. Аронов, М. Г. Бубнова, Г. В. Погосова [и др.] // Кардиология. - 2006. - № 2. - С. 86-99.
Висновки. Таким чином, відновлювальне лікування $€$ необхідною частиною комплексного лікування хворих з IXC після хірургічної реваскуляризації міокарда. Санаторний етап реабілітації сприяє зниженню ризику прогресування IXC, зменшенню рецидивів стенокардії та кількості госпіталізацій протягом 12 місяців спостереження.

2. Аронов Д. М. Функциональные пробы в кардиологии / Д. М. Аронов, В. П. Лупанов. - М. : Дпресс-информ, 2002. -302 c.

3. Группы высокого риска смертности от болезней системы 
кровообращения у лиц с артериальной гипертензией (по данным десятилетнего когортного исследования) / В. П. Подпалов [и др.] // Кардиология в Беларуси. - 2011. - № 4. С. 75-85.

4. Книшов Г. В. Прогресування коронарного атеросклерозу як можливий наслідок екзогенних втручань: коронарного шунтування та стентування / Г. В. Книшов, О. В. Левчишина // Укр. кардіол. журн. - 2010. - Т. 14, № 2. - С. 72-76.

5. Лутай М. И. Ведение больных с ишемической болезнью сердца и сопутствующей артериальной гипертензией в Украине. Результаты исследования ПРЕСТИЖ / М.И. Лутай // Український кардіологічний журнал. - 2011. - № 1. - С. 25-36.

6. ESC Guidelines on myocardial revascularization //

\section{REFERENCES}

1. Aronov, D.M., Bubnova, M.G. \& Pogosova, G.V. (2006). Reabilitatsiya bolnykh ishemicheskoy boleznyu serdtsa na dispanserno-poliklinicheskom etape [Rehabilitation of patients with ischemic heart disease at the dispensary-polyclinic stage]. Kardiologiya - Cardiology, 1, 11-17 [in Russian].

2. Aronov, D.M. \& Lupanov, V.P. (2002). Funktsionalnyye proby $v$ kardiologii [Functional tests in cardiology]. Moscow: Dprs-inform [in Russian].

3. Podpalov, V. P. (2011). 51 Gruppy vysokogo riska smertnosti ot bolezney sistemy krovoobrashcheniya u lits s arterialnoy gipertenziyey (po dannym desyatiletnego kogortnogo issledovaniya) [51 Groups of high risk of mortality from diseases of the circulatory system in persons with arterial hypertension (according to the data of a ten-year cohort study)]. Kardiologiya v Belarusi - Cardiology in Belarus, 4, 75-85 [in Russian].

4. Knyshov, G.V. \& Levchyshina, A.V. (2010). Prohresuvannia koronarnoho aterosklerozu yak mozhlyvyi naslidok ekzohennykh vtruchan: koronarnoho shuntuvannia ta stentuvannia [Progression of coronary atherosclerosis as a possible consequence of exogenous interferences: coronary bypass and stenting]. Ukr. kardiol. Zhurn Ukrainian Cardiology Journal, 14 (2), $72-76$ [in Ukrainian].

5. Lutay, M.I. (2011). Vedeniye bolnykh s ishemicheskoy
Eur. Heart J. - 2010. - Vol. 31. - P. 2501-2555.

7. Salim Yusuf. Deciphering the causes of cardiovascular and other complex diseases in populations: achievements, challenges, opportunities, and approaches / Yusuf Salim, Anand Sonia // Progress in Cardiovascular Diseases. - 2010. - Vol. 53, No. 1. - P. 62-67.

8. Марченко О. К. Фізична реабілітація осіб із ішемічною хворобою серця з синдромом інсулінорезистентності / О. К Марченко, І. Н. Євстратова, М. Алшбул // Теорія та методика фізичного виховання і спорту. - 2012. - № 1. - С. 77-80. 9. Оганов Р. Г. Профилактическая кардиология: надежды и реальность / Р. Г. Оганов // Здравоохранение. - 2012. - № 9. - C. 60-67.

boleznyu serdtsa i soputstvuyushchey arterialnoy gipertenziyey v Ukraine. Rezultaty issledovaniya PRESTIZH [Management of patients with coronary heart disease and concomitant arterial hypertension in Ukraine. Results of the research PRESTIGE]. Ukrainskyi kardiologichnyi zhurnal - Ukrainian Cardiological Journal, 1, 25-36 [in Russian].

6. (2010). ESC Guidelines on myocardial revascularization. Eur. Heart J., 31, 2501-2555.

7. Salim Yusuf \& Anand Sonia (2010). Deciphering the causes of cardiovascular and other complex diseases in populations: achievements, challenges, opportunities, and approaches. Progress in Cardiovascular Diseases, 53, 1, 62-67.

8. Marchenko, O.K., Yevstratova, I.N. \& Alshbul, M. (2012). Fizychna reabilitatsiia osib iz ishemichnoiu khvoroboiu sertsia $\mathrm{z}$ syndromom insulinorezystentnosti [Physical rehabilitation of persons with ischemic heart disease with insulin resistance syndrome]. Teoriia ta metodyka fizychnoho vykhovannia i sportu - Theory and Methods of Physical Education and Sport, 1, 77-80 [in Ukrainian].

9. Oganov, R.G. (2012). Profilakticheskaya kardiologiya: nadezhdy i realnost [Preventive cardiology: hope and reality]. Zdravookhraneniye - Health Care, 9, 60-67 [in Russian].

Отримано 17.08.2017

\section{O. V. KOLODENKO}

Ukrainian Research Institute of Medical Rehabilitation and Balneology of Ministry of Health of Ukraine, Odesa

\section{GLINICAL EFFICACY IN THE RESTORED PERIOD OF RECOVERY TREATMENT OF PATIENTS WITH ISCHEMIC HEART DISEASE AFTER SURGICAL REVASCULARIZATION OF PATIENTS}

\footnotetext{
The aim of the work - to examine the clinical efficacy of the remote period of the sanatorium stage of rehabilitation of patients with coronary heart disease after surgical myocardium revascularization.

Materials and Methods. 151 patients with coronary heart disease after surgical myocardium revascularization (SMR) were examined. 111 patients in the main group received renewal treatment. The course of treatment was 21 days, after which recommendations for lifestyle modification were provided. Patients in the comparison group (40 people) did not receive rehabilitation treatment. Long-term results were studied according to the outpatient card data of patients (myocardial infarction for 12 months after SMR, the number of hospitalizations on IHD complications, and the number of angina attacks), all non-invasive studies were performed in all patients, which included ECG, echocardioscopy. With the purpose of diagnosing lesions of the coronary tract, patients with a positive breakdown on bicycle ergometer (BEM) underwent coronary angiography.

Results and Discussion. According to BEM, in $7.5 \%$ of patients who did not undergo a renewal treatment, signs of myocardial ischemia were detected in $1.5 \%$ of patients in the main group. The number of attacks of angina, which resulted in a repeated procedure for revascularization (percutaneous coronary intervention), was found in 3 (2.7\%) patients in the main group, while in the comparison group it was more likely that $5(12.5 \%)$ of patients $(\mathrm{p}<0.05)$.
}

Key words: ischemic heart disease; surgical revascularization of myocardial disorders; delay results; renewal treatment. 


\section{Е. В. КОЛОДЕНКО}

ГУ “Украинский НИИ медицинской реабилитации и курортологии МЗ Украины”, Одесса

\section{К.ЛИНИЧСКАЯ ЭФФЕКТИВНОСТЬ В ОТДАЛЕННЫЙ ПЕРИОД ВОССТАНОВИТЕЛЬНОГО ЛЕЧЕНИЯ БОЛЬНЫХ С ИШЕМИЧЕСКОЙ БОЛЕЗНЫЮ СЕРДЦА ПОС.ЛЕ ХИРУРГИЧЕСКОЙ РЕВАСКУЛЯРИЗАЦИИ БОЛЬНЫХ}

Цель работы: изучить клиническую эффективность в отдаленный период санаторного этапа реабилитации больных с ИБС после ХРМ.

Материалы и методы. Было обследовано 151 пациентов с ИБС после хирургической реваскуляризации миокарда (ХРМ). 111 пациентов основной группы прошли санаторное лечение. Курс лечения составил 21 день, после которого были даны рекомендации по модификации образа жизни. Пациенты группы сравнения (40 человек) не получали санаторного лечения. Отдаленные результаты изучали по данным амбулаторных карт пациентов (наличие инфаркта миокарда в течение 12 месяцев после ХРМ, количество госпитализаций по поводу осложнений ИБС, количество приступов стенокардии), всем пациентам проводили неинвазивные исследования, которые включали ЭКГ, ЭХОКС. С целью диагностики поражений коронарного русла пациентам с положительной пробой на велоэргометре (ВЭМ) проводили коронарографию.

Результаты исследований и их обсуждение. По данным ВЭМ, в 7,5\% пациентов, не проходивших санаторный этап лечения, были выявлены признаки ишемии миокарда, в то время как в основной группе - у 1,5 \%. Количество приступов стенокардии, в результате которой была проведена повторная процедура реваскуляризации (черезкожное коронарное вмешательство), в основной группе было выявлено у 3 (2,7 \%) пациентов, в то время как в группе сравнения достоверно большим - у 5 (12,5 \%) пациентов ( $<0,05)$.

Ключевые слова: ишемическая болезнь сердца; хирургическая реваскуляризация миокарда; отдаленные результаты; санаторный этап. 